\title{
OPTIMAL UTILIZATION OF CONSTRUCTION RESOURCES FOR EFFICIENT PROJECT
}

\section{RAFIULLAH AMIRI \& SANDEEP SALHOTRA}

Chandigarh University, Mohali, Chandigarh, India

\begin{abstract}
Construction industries are seeking to save cost and time in construction projects. Therefore they need a framework to adjust all activities and resources optimally, optimal utilization of resources is capable based on the EEE (Effectiveness, Efficiency, and Economy) of resources. Additionally, the virtual possibility of EEE is linked to the waste management of construction's resources. It means the reduction and elimination of wastages in Material, Equipment, labors, time and money. Wastages in construction are breaking down in these types: D.O.W.N.T.I.M.E or defects, overproduction, waiting, none utilized talent/resources, transportation, Inventory excess, Motion excess, and extra processing. The main aim of this study is the optimal utilization of construction's resources on the basis of methods which have been used in manufacture industries and utilization of Internet of Things (IOT) for closed monitoring and controlling of these resources to avoid wastages in execution process and gain the planned productivity, for this purpose we have used specific method for each resource individually and integrated them with IOT. The methods are: Just-In-Time (JIT-IOT) model for material management, 2-Total Productive Maintenance (TPM-IOT) model for equipment's optimization.3- (KaizenIOT) model for labor-management. Finally, the utilization of lean methods and technology in construction projects provided an optimal planning, implementation and monitoring \& controlling of resources, which giving us better productivity, safety, quality and also give the time for site management team to focus on other tasks of project to gain the optimal result.
\end{abstract}

KEYWORDS: Construction Resources; Optimal Utilization; Internet of Things; Waste Management; Framework

Received: May 09, 2019; Accepted: Jun 29, 2020; Published: Jun 30, 2020; Paper Id.: IJMPERDJUN2020234

\section{INTRODUCTION}

Construction projects require close management to fulfill all related requirements and establish relationship between project's variables; Time and quality are more essential objectives for construction industries and for project management team in construction projects to be managed in same time, but the more important variable that directly affects the time and quality, that is the resources utilization which includes: material, equipment, labors, money, and space or time management and optimal utilization of these resources as per conditions of project. For avoiding and reducing of wastages in construction resources from the planning process up to closing process we have considered the Lean Construction Principles as following:1- Identify value from the customer's point of view.2- Define the value stream 3- Eliminate waste 4- Flow of work processes .5- Pull planning and scheduling 6Continuous improvement. Researchers have done researches for allocation of resources, management and utilization of resources separately for each resource like for equipment, material, labors as just one of them but there is not any general framework for all resources to integrate the resources for optimal utilization of them, so we have provided a framework for all resources in same time and also defined specific method for each resource, this framework facilitates the utilization of resources as optimally for construction industries and for project 
management team, long-term resource requirements in general planning and short-term resource requirement in detailed planning, this study provides the following sections:Secion-1 display the optimal utilization of material based on Just-inTime or JIT method, Section-2 exhibit the equipment management and maintenance of equipment on the basis of Total Productive Maintenance or TPM method, Section-3 presents the labors management through Kaizen method[1], Section-4 demonstrate IOT utilization integrated to each of the mentioned method for better monitoring and controlling of construction resources at site,Section-5 illustrates the questionnaire result that collected from various experts of this field, Section-6 appear the case study on construction project which has been implemented by conventional method and compare to the proposed model and shown the effective result for time and cost of project. The previous researches offered the following studies in similar concept but not exact same to this study, the main reason behind these manufacturing methods or production philosophy is that these methods are able to do as lean all the activities and processes or we can say these methods are with less time, best quality and with high level of profit for manufactures as well as in construction industries [2].This paper recommended the utilization of IOT with these lean methods for optimal utilization of construction resources.

\section{LITERATURE REVIEW}

PMBOK 2017, PMI or Project Management Institute one of the updated and professional institutes in today's project management field provided the Project management body of knowledge Book or PMBOK $20176^{\text {th }}$ edition, it has referred the methods for resources management i.e. Just in Time method or JIT, Kaizen method, Total Productive Maintenance (TPM) method, in this book there is just the names of methods for resource management but these methods and this data can convert to information and knowledge for construction industries to use as practically in construction projects, so this paper provides the integration of these methods as framework for optimal utilization of resources in the best way and with help of these mentioned methods and techniques [1].J. Rama Jogi studied the optimal utilization of resources in construction industry with the help of controlling the wastages of construction resources and he found that without the leveling of resources no extra activity should be performed because the time consumed as fixed program [3]. The same topic studied by Fapohunda but with the reflections of project managers' attributes, it means the optimal utilization of construction resources with the reflections of project managers' attributes and highlighted some factors for efficient utilization of resources that are, adequate knowledge transfer, timely availability of resources, team integration and team building [4]. Kumar studied the productivity increase by optimum utilization of resources and he indicates five productivity factors i.e. leadership, strategic quality planning, people, data and information and process management, and also he found that the optimal utilization of machinery and machine productivity is better than labors but if increase the numbers of labors it also can increase productivity, machine productivity calculated with the following formula: Machine productivity $=$ Total productivity/ No. of Machines.[5].Zhao,2019 studied the resource tracking in real-time with the basis of real-time tracking system to collect data from various locations, they have applied Bluetooth Low Energy (BLE) technology and real-time location sensors or (RTLS) for tracking the workers and them locations in site for avoiding waste of productivity [6].Vahdate,2018 has done research about the lean management, principles, techniques and its applicability in construction projects, they hoped to reduce the wastages in construction processes, raise the quality of work, and also raise the level of profit [7].

Lauri,1992 has provided the methods and techniques which are used in manufactures and production industries to use these methods in construction as well as new production philosophy, the methods which are mentioned there are JIT 
Method, TPM Method, Total Quality Control (TQC),[2].Kaiafa,2015 has studied and optimization method for multiobjective resource-constrained scheduling, this optimization tried to reduce the total cost that comes out from, a- over location of resources, b- project deadline significance, c-fluctuations of resource day-by-day, they have concluded to impound the daily resource utilization within resource presence, completion the project as soon as possible, and create the daily resource histogram as smooth as possible [8].S.Tang,2019 studied the IOT with BIM or Building Information Modeling, the researcher integrated them and create a model as BIM-IOT, this model has been suggested for different domain of construction works as construction operation and monitoring, On-site environment monitoring, resource monitoring, communication and collaboration, construction performance and progress monitoring, health and safety management, H\&S training, On-site monitoring for H\&S, Construction logistic and management, automation in prefabrication, lean construction, facility management and the researcher recommended this model for better controlling of construction site[9].R. Woodhead 2018 has done the research for digital construction based on Internet of Things or IOT , he researched about the UK Construction companies and their ecosystem and the authors recommended this innovation to construction companies for better and controlled environment based on digital layer[10].R. Kanan 2018, studied the IOT based autonomous system for worker's safety in construction site and real-time alarming, monitoring and positioning strategies. The researcher has done with radio frequency system and IOT wearable's for workers' safety and utilized the wireless nodes for management of indoor and outdoor environment management[11].

\section{METHODOLOGY AND METHODS}

The methodology for optimal utilization of construction resources which are material, equipment and labor observed into two parts, the first one is lean methods that are JIT for material, TPM for equipment and Kaizen method for labor utilization. The actual implementation of these methods need for closed monitoring and controlling which IOT doing this job. With the help of these two aspects we have created a general framework for construction industries. For the actualization and proof of the concept we have done case study and questionnaire. The results of case study and questionnaire discussed and analyzed separately. The summary of this research collected on conclusion part for providing the short and simple proposed model and its implementation.

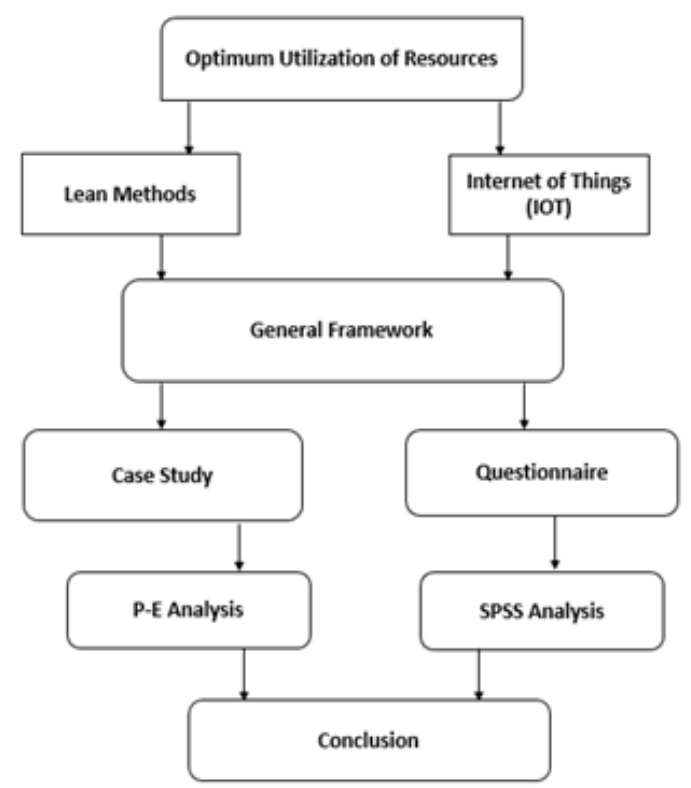

Figure 1: Methodology for Research. 


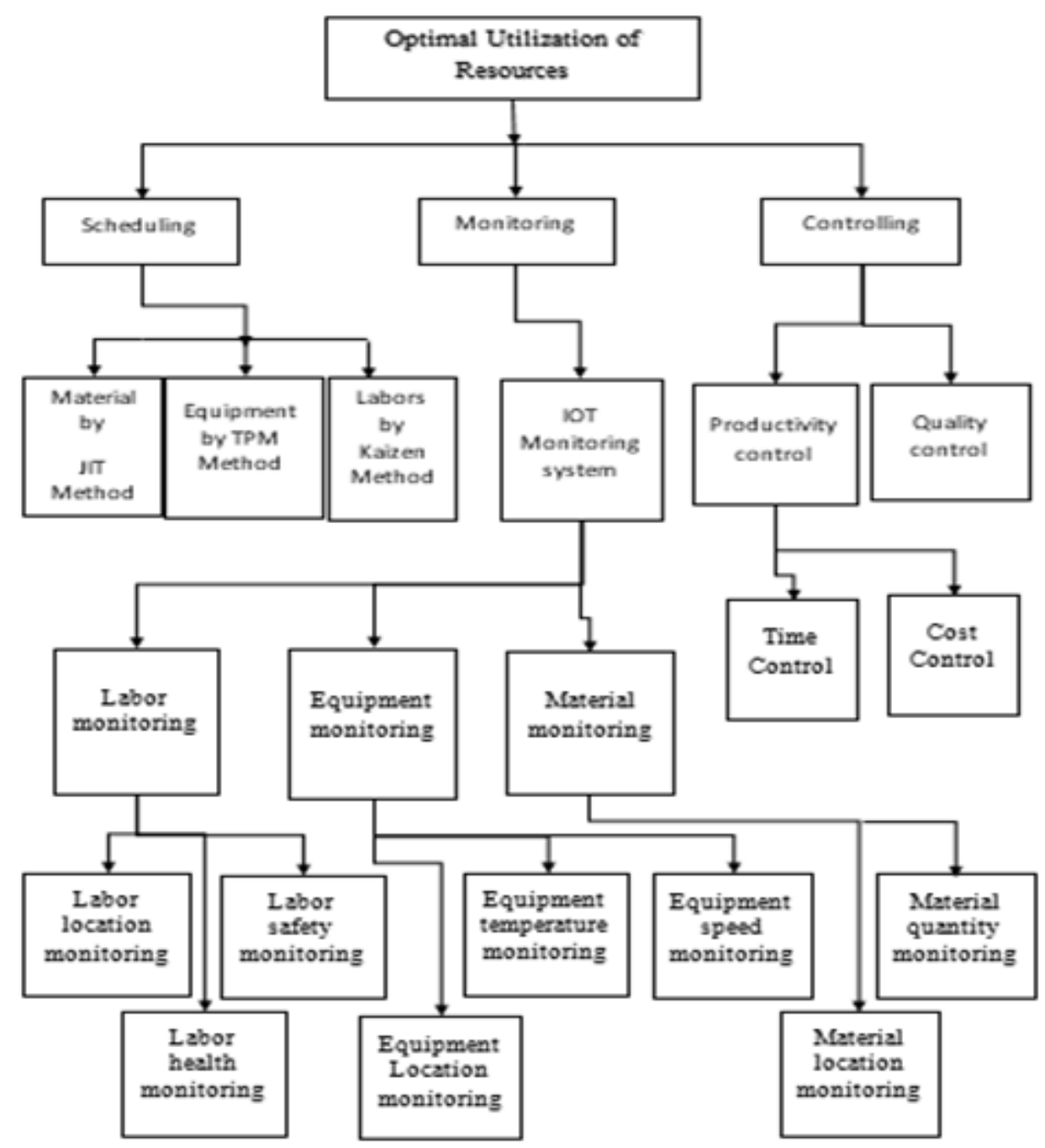

Figure 2: General Framework of Lean Methods with IOT for Optimum Utilization of Construction Resources.

\section{MATERIAL UTILIZATION}

Just in Time or JIT is a lean methodology to increase efficiency, decrease cost and waste by receiving materials only just they are required. A- Insignificant or zero inventory. B-Zero breakdowns. C-100\% on-time delivery system. D-Elimination of no value activities. E-Zero defects. 


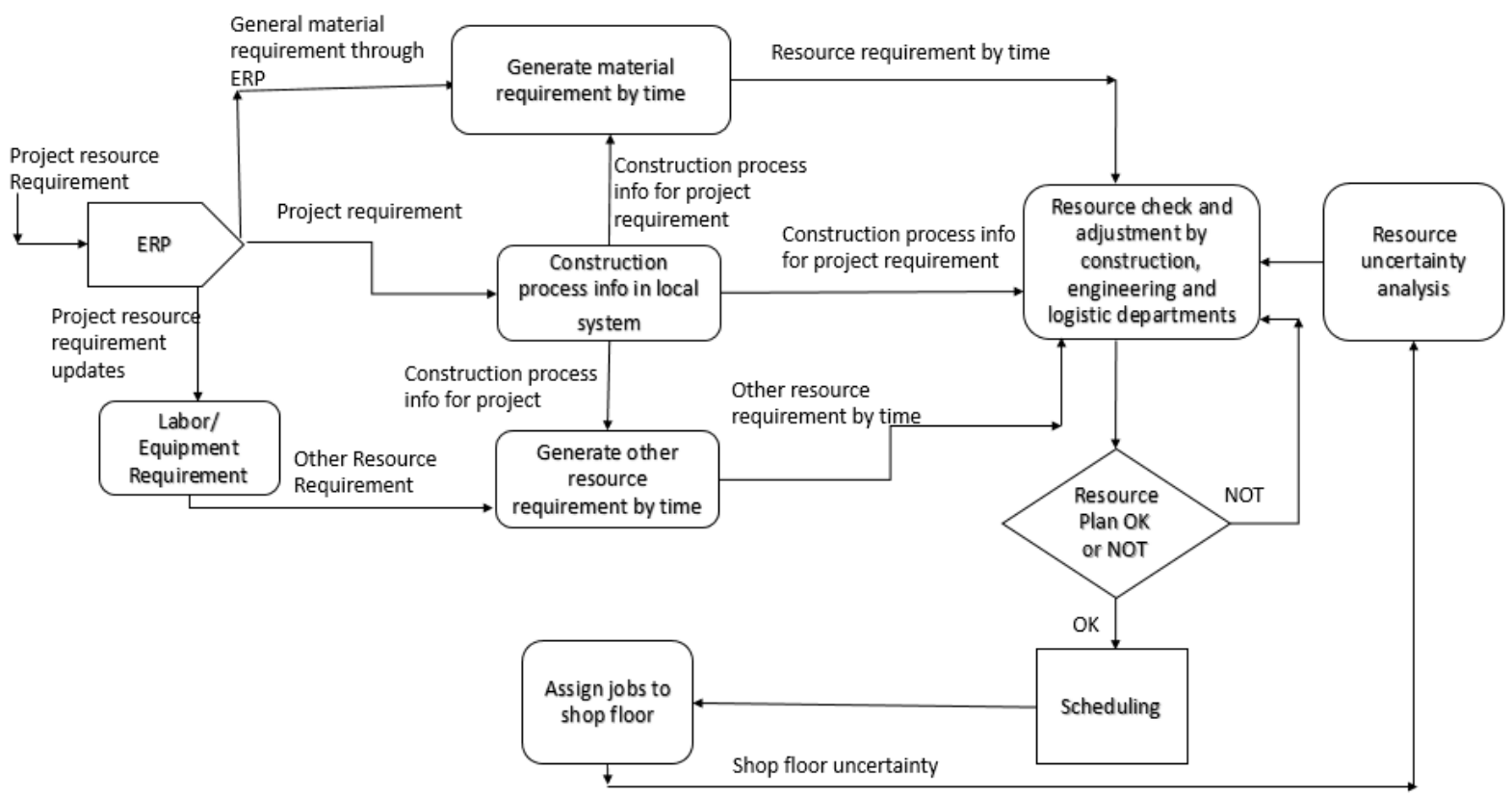

Figure 3: JIT General Scheduling Process Flow for Resources.

The IOT based flow chart for material and other resource became simple the flow of utilization of resources and its management, the following flow chart shows the material utilization for construction project with help of JIT method and monitoring and controlling with IOT.

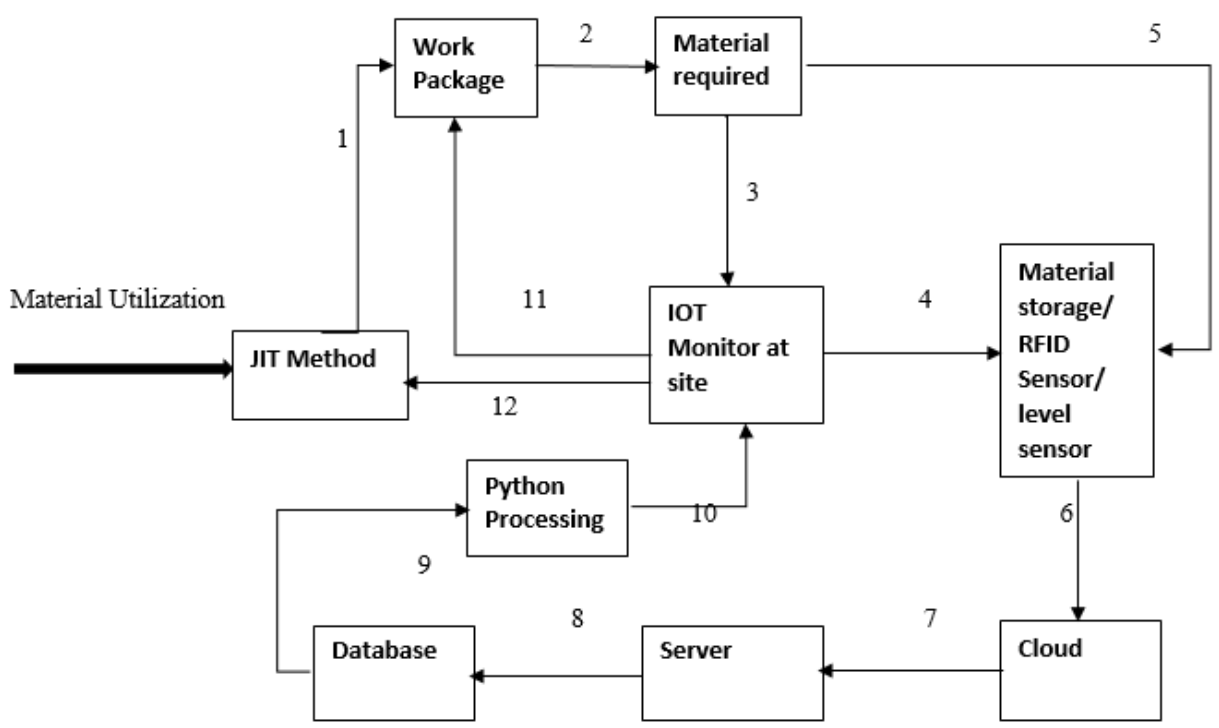

Figure 4: JIT-IOT Framework for Material Utilization Real-Time Resource Status Monitoring Module.

\section{EQUIPMENT UTILIZATION THROUGH TPM}

Total Productive Maintenance defined in three parts individually. The word Total means involving all aspects, elements, participants, resources, etc. Productive means, producing more output with the same or fewer inputs, if we are productive we have the power of producing, generative and creative as well. Finally, the word maintenance means activities that are 
designed to keep asset in good condition and not let deteriorate in the first place. The TPM main two aspects are: 1- A rigorous approach to achieving high machine utilization and accurate measurement.2-A shop floor philosophy based on encouraging operators to take a greater role in the health of their equipment and the productivity of the construction process. Two confusions to be avoiding them are: 1-Maintenance means repair? 2-The different between TMP and TQM ? Many people think the maintenance means repair or fix, but actually the maintenance is activity that avoids the need to repair. On other hand, the Total Quality Management or TQM focuses on the quality of the product, while TPM focuses on the equipment used to produce the products. By preventing equipment break-down, improving the quality of the equipment and by standardizing the equipment (results in less variance, so better quality), the quality of the products increases. TQM and TPM can both result in an increase in quality. However, the way of going there is different. TPM can be seen as a way to help to achieve the goal of TQM. The main aim of this research paper regarding to equipment maintenance is to manage the equipment in good condition before breakdown and deterioration.

\section{Objectives of TPM}

- Reduce equipment breakdowns and emergencies.

- Increase overall equipment effectiveness (OEE).

- Improved productivity.

- Improved safety.

- More emphasis in preventive work.

- More emphasis on getting to the root of the problem and eliminating it.

- Lower operating cost.

- Reduce wait time for maintenance craftsman.

- Improved equipment lifespan.

- Training for equipment's' operators.

Furthermore, the operators of equipment, supervisor and managers are responsible to be attentive for equipment before utilization, during utilization and after finishing the tasks. The operators' benefits in TPM are: Increases decisionmaking regarding equipment, ability to address issues that plagued progress, better relationship with maintenance, Multiskilled operators in higher demand. Additionally, the supervisors and managers' stakeholder group are significantly convinced about TMP and its achievements. Benefits of supervisors and managers in TPM are: Higher skilled operators, Smoother progress, Easier to meet goals when everyone is pulling the same direction, higher worker morale from improved job satisfaction and job safety, more cooperative work environment from team work, better relationship with maintenance, more challenges and more fun. We have provided a framework for equipment utilization on the basis of TPM method that can be a helpful one for construction industries, the framework is as following: 


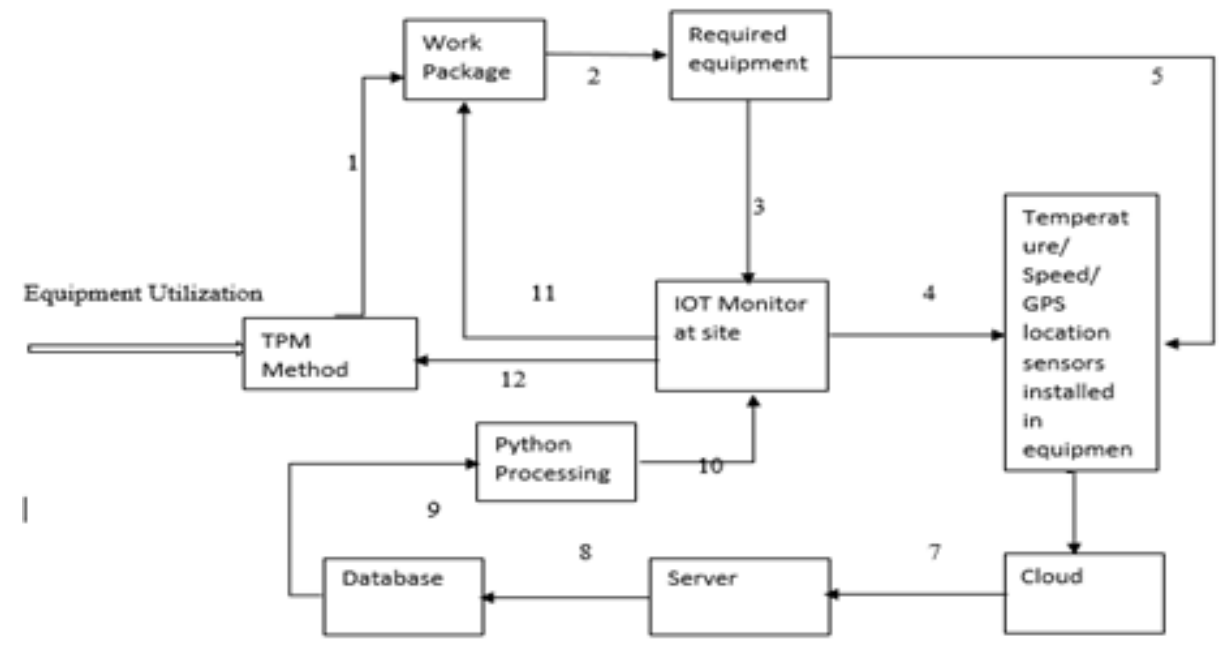

Figure 5: Equipment Utilization Framework through TPM and IOT.

\section{LABOR UTILIZATION THROUGH KAIZEN METHOD}

Kaizen means continuous improvement, which can be applied to steadily enhance our personal, family, social and work lives. When applied to the workplace, Kaizenmeans continuous improvement for all human resources, managers, and workers. Labor productivity, which is also known as workforce productivity, is defined as the economic output per labor hour, a labor hours' calculator can help organizations to determine their labor productivity. Some recommendations:

- Best Productivity Apps

- $\quad$ Effective Leadership

- Best Productivity Systems for Work.

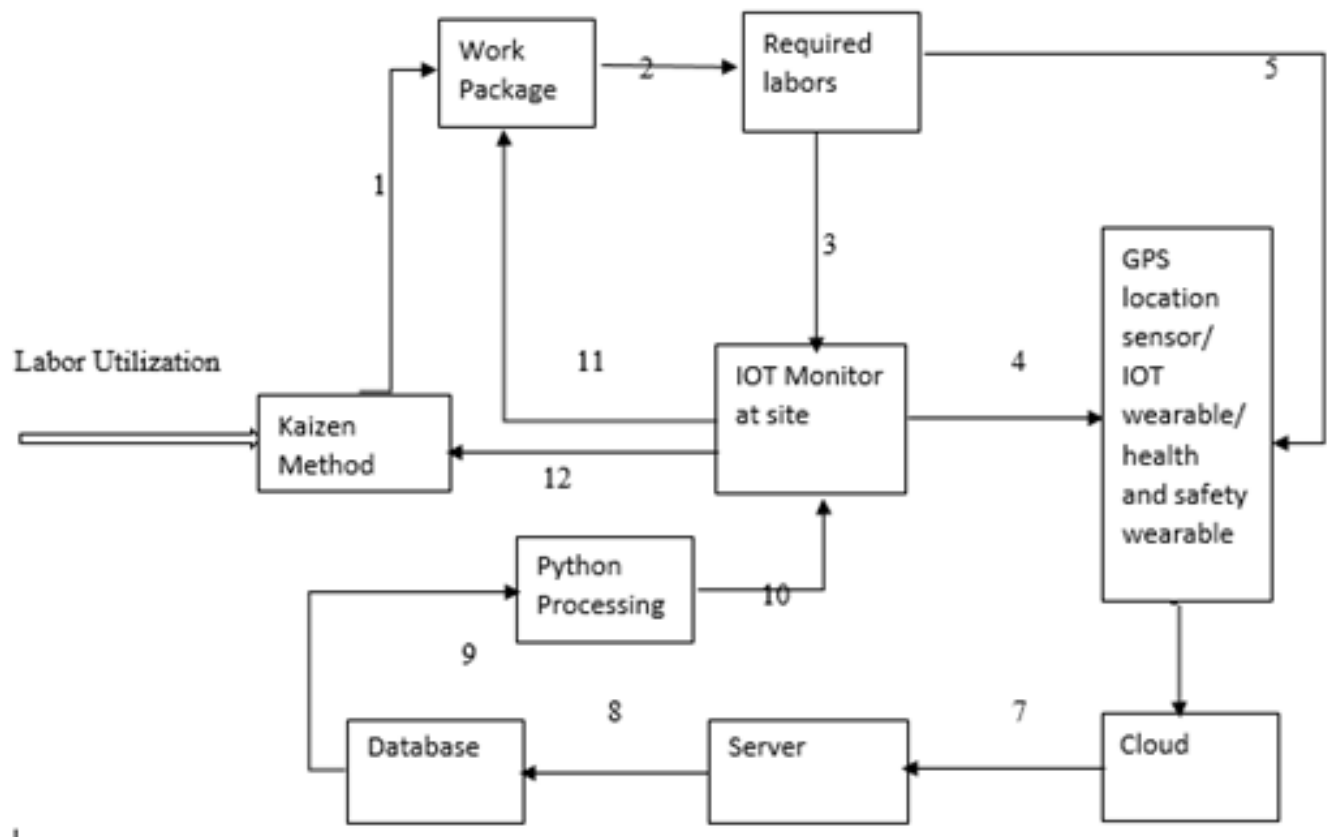

Figure 6: Frame Work for Labor Utilization through Kaizen Method and IOT. 


\section{CASE STUDY}

The following table is the summaries of case study that done by the construction project. MEW/B-039 New building contracted and implemented by Afghan Safid Cheher Construction Company. At Dashtak of Panjshir Province. Afghanistan. This analysis carried out by product-quantity or P-Q analysis method which is one of the lean method in Manufacture Company of TOYOTA Japan. The table show the productivity of activities listed in table. While we utilized the lean methods with IOT technology. It avoid all the mentioned wastages and the productivity gained as per planned and standard schedule of project. When the productivity gained as per planned, the cost and time saved optimally.

Table 1: Case Study and P-E Analysis (Productivity-Efficiency) Analysis

\begin{tabular}{|c|c|c|c|}
\hline \multicolumn{2}{|c|}{ Conventional Method } & \multicolumn{2}{|c|}{$\begin{array}{c}\text { Recommended New Method through Lean } \\
\text { Methods and IOT }\end{array}$} \\
\hline Project Name & $\begin{array}{l}\text { Construction of } 3 \text { story new } \\
\text { building with road and park }\end{array}$ & Project Name & $\begin{array}{l}\text { Construction of } 3 \text { story new } \\
\text { building with road and park }\end{array}$ \\
\hline Type of Project & Administration Building & Type of Project & Administration Building \\
\hline Project ID & MEW/B-039 & Project ID & MEW/B-039 \\
\hline Client Name & $\begin{array}{l}\text { Ministry of Energy and Water ( } \\
\text { MEW) }\end{array}$ & Client Name & $\begin{array}{l}\text { Ministry of Energy and Water } \\
(\text { MEW) }\end{array}$ \\
\hline Contractor Name & $\begin{array}{l}\text { Afghan Safid Cheher } \\
\text { Construction Company (ASCC) }\end{array}$ & Contractor Name & $\begin{array}{l}\text { Afghan Safid Cheher } \\
\text { Construction Company } \\
\text { (ASCC) }\end{array}$ \\
\hline Project Location & Panjshir Province Afghanistan & Project Location & $\begin{array}{l}\text { Panjshir Province } \\
\text { Afghanistan }\end{array}$ \\
\hline Project Total Cost & $27606267.00 \mathrm{AFN}$ & Project Total Cost & $27606267.00 \mathrm{AFN}$ \\
\hline $\begin{array}{l}\text { Project Planned } \\
\text { Cost after } 15 \% \\
\text { Profit margin } \\
\end{array}$ & $23465326.95 \mathrm{AFN}$ & $\begin{array}{l}\text { Project Planned Cost } \\
\text { after } 15 \% \text { Profit } \\
\text { margin }\end{array}$ & $23465326.95 \mathrm{AFN}$ \\
\hline $\begin{array}{l}\text { Material Planned } \\
\text { Cost }\end{array}$ & 15252462.51 AFN & $\begin{array}{l}\text { Material Planned } \\
\text { Cost }\end{array}$ & $15252462.51 \mathrm{AFN}$ \\
\hline $\begin{array}{l}\text { Equipment Planned } \\
\text { Cost }\end{array}$ & 3519799.04 AFN & $\begin{array}{l}\text { Equipment Planned } \\
\text { Cost }\end{array}$ & 3519799.04 AFN \\
\hline Labor Planned Cost & 4693065.39 AFN & Labor Planned Cost & 4693065.39 AFN \\
\hline Project Actual Cost & 26985125.9925 AFN & Material actual cost & $14079196.17 \mathrm{AFN}$ \\
\hline Material actual cost & $16425728.865 \mathrm{AFN}$ & $\begin{array}{l}\text { Equipment actual } \\
\text { cost }\end{array}$ & 2346532.695 AFN \\
\hline $\begin{array}{l}\text { Equipment actual } \\
\text { cost }\end{array}$ & 4693065.39 AFN & labors actual cost & $3519799.0425 \mathrm{AFN}$ \\
\hline labors actual cost & $5866331.7375 \mathrm{AFN}$ & Project Actual Cost & 19945527.9075 AFN \\
\hline $\begin{array}{l}\text { Difference } b / w \\
\text { Planned and Actual } \\
\text { Cost }\end{array}$ & 3519799.0425 AFN & $\begin{array}{l}\text { Difference b/w } \\
\text { Conventional } \\
\text { Method and New } \\
\text { recommended } \\
\text { method }\end{array}$ & $\begin{array}{l}26985125.9925- \\
19945527.9075=\mathbf{7 0 3 9 5 9 8 . 0 8 5} \\
\text { AFN }\end{array}$ \\
\hline $\begin{array}{l}\text { Reason for } \\
\text { Difference cost of } \\
\text { Material }\end{array}$ & $\begin{array}{l}\text { 1- Insufficient Planning Method } \\
\text { 2- Insufficient Monitoring and } \\
\text { Controlling, 3- wastages }\end{array}$ & $\begin{array}{l}\text { Response for } \\
\text { avoiding difference } \\
\text { cost of material }\end{array}$ & $\begin{array}{l}\text { 1- JIT Method for Sufficient } \\
\text { Planning 2- IOT for } \\
\text { Monitoring 3- Dynamic } \\
\text { Scheduling through IOT and } \\
\text { JIT for controlling }\end{array}$ \\
\hline
\end{tabular}




\begin{tabular}{|c|c|c|c|}
\hline $\begin{array}{l}\text { Reason for } \\
\text { Difference cost of } \\
\text { equipment }\end{array}$ & $\begin{array}{l}\text { 1- Insufficient Planning Method } \\
\text { 2- Insufficient Monitoring and } \\
\text { Controlling, 3- wastages }\end{array}$ & $\begin{array}{l}\text { Response for } \\
\text { avoiding difference } \\
\text { cost of equipment }\end{array}$ & $\begin{array}{l}\text { 1- TPM Method for } \\
\text { Sufficient Planning 2- IOT } \\
\text { for Monitoring 3- Dynamic } \\
\text { Scheduling through IOT and } \\
\text { TPM for controlling }\end{array}$ \\
\hline
\end{tabular}

Table 1: Contd.,

\begin{tabular}{|c|c|c|c|}
\hline $\begin{array}{l}\text { Reason for } \\
\text { Difference cost of } \\
\text { labors }\end{array}$ & $\begin{array}{l}\text { 1- Insufficient Planning Method } \\
\text { 2- insufficient Monitoring and } \\
\text { Controlling, 3- wastages }\end{array}$ & $\begin{array}{l}\text { Response for } \\
\text { avoiding difference } \\
\text { cost of labor }\end{array}$ & $\begin{array}{c}\text { 1- Kaizen Method for } \\
\text { Sufficient Planning 2- IOT } \\
\text { for Monitoring 3- Dynamic } \\
\text { Scheduling through IOT and } \\
\text { Kaizen for controlling }\end{array}$ \\
\hline $\begin{array}{l}\text { Material } \\
\text { productivity } \\
\text { Output(Planned } \\
\text { Cost)/Input (actual } \\
\text { cost) }\end{array}$ & $\begin{array}{l}15252462.51 \mathrm{AFN} / 16425728.865 \\
\mathrm{AFN}=0.93\end{array}$ & $\begin{array}{l}15252462.51 \\
\text { AFN/14079196.17 } \\
\text { AFN }\end{array}$ & 1.08 \\
\hline $\begin{array}{l}\text { Equipment } \\
\text { productivity } \\
\text { Output(Planned } \\
\text { Cost)/Input (actual } \\
\text { cost) }\end{array}$ & $\begin{array}{l}3519799.04 \quad \mathrm{AFN} / 4693065.39 \\
\mathrm{AFN}=0.75\end{array}$ & $\begin{array}{l}3519799.04 \\
\text { AFN/2346532.695 } \\
\text { AFN }\end{array}$ & 1.50 \\
\hline $\begin{array}{l}\text { Labor productivity } \\
\text { Output(Planned } \\
\text { Cost)/Input (actual } \\
\text { cost) }\end{array}$ & $\begin{array}{l}4693065.39 \quad \mathrm{AFN} / 5866331.7375 \\
\mathrm{AFN}=0.80\end{array}$ & $\begin{array}{l}4693065.39 \\
\text { AFN/3519799.0425 } \\
\text { AFN }\end{array}$ & 1.33 \\
\hline $\begin{array}{l}\text { Total resource } \\
\text { Productivity } \\
\text { Output(Planned } \\
\text { Cost)/Input (actual } \\
\text { cost) }\end{array}$ & $\begin{array}{l}23465326.95 \\
\text { AFN/26985125.9925 AFN=0.87 }\end{array}$ & $\begin{array}{l}23465326.95 \\
\text { AFN/19945527.9075 } \\
\text { AFN }\end{array}$ & 1.18 \\
\hline $\begin{array}{l}\text { Material Efficiency } \\
(\%) \text { Output(Planned } \\
\text { Cost)/Input (actual } \\
\text { cost)*100 }\end{array}$ & $\begin{array}{l}15252462.51 \mathrm{AFN} / 16425728.865 \\
\mathrm{AFN} * 100 \%=92.86\end{array}$ & $\begin{array}{l}15252462.51 \\
\mathrm{AFN} / 14079196.17 \\
\mathrm{AFN} * 100\end{array}$ & 108.33 \\
\hline $\begin{array}{l}\text { Equipment } \\
\text { Efficiency }(\%) \\
\text { Output(Planned } \\
\text { Cost)/Input (actual } \\
\text { cost)*100 }\end{array}$ & $\begin{array}{l}3519799.04 \text { AFN } / 4693065.39 \\
\mathrm{AFN}^{*} 100 \%=75.00\end{array}$ & $\begin{array}{l}3519799.04 \\
\text { AFN/2346532.695 } \\
\text { AFN*100 }\end{array}$ & 150.00 \\
\hline $\begin{array}{l}\text { Labor Efficiency } \\
(\%) \text { Output(Planned } \\
\text { Cost)/Input (actual } \\
\text { cost)*100 }\end{array}$ & $\begin{array}{l}4693065.39 \text { AFN } / 5866331.7375 \\
\mathrm{AFN}^{*} 100 \%=80.00\end{array}$ & $\begin{array}{l}4693065.39 \\
\text { AFN/3519799.0425 } \\
\text { AFN*100 }\end{array}$ & 133.33 \\
\hline $\begin{array}{l}\text { Total resource } \\
\text { efficiency }(\%) \\
\text { Output(Planned } \\
\text { Cost)/Input (actual } \\
\text { cost)*100 }\end{array}$ & $\begin{array}{l}23465326.95 \\
\text { AFN/26985125.9925 } \\
\text { AFN*100=87.00 }\end{array}$ & $\begin{array}{l}23465326.95 \\
\text { AFN/19945527.9075 } \\
\text { AFN*100 }\end{array}$ & 117.65 \\
\hline $\begin{array}{l}\text { Productivity } \\
\text { Difference }\end{array}$ & 0.87 & 1.18 & 0.31 \\
\hline $\begin{array}{l}\text { Efficiency (\%) } \\
\text { Difference }\end{array}$ & 87 & 117.76 & 30.76 \\
\hline
\end{tabular}




\section{QUESTIONNAIRE ANALYZING OR TESTS}

\section{Correlations}

Based on the above table, Project efficiency have the high degree of correlation with JIT with IOT and, it means, there is strong positive relation between the usage of JIT method with IOT and project efficiency whereby the value of correlation is $(\mathrm{r}=.864, \mathrm{p}<.05)$, Kaizen with IOT also have the high degree of correlation the project efficiency $(\mathrm{r}=.802, \mathrm{p}<.05)$, and TPM with IOT have moderate degree of correlation project efficiency because the $r$ value is between $(r=0.75-0.5$, p $<0.5)$. In the table it shows that every variable are significant because $\mathrm{P}$ value are not more than 0.05 .

Table 2: Correlation between the Methods, IOT and Efficiency

\begin{tabular}{|c|c|c|c|c|c|}
\hline \multicolumn{6}{|c|}{ Correlations } \\
\hline & & $\begin{array}{l}\text { JIT with } \\
\text { IOT }\end{array}$ & $\begin{array}{l}\text { TPM whit } \\
\text { IOT }\end{array}$ & $\begin{array}{c}\text { Kaizen with } \\
\text { IOT }\end{array}$ & $\begin{array}{c}\text { Project } \\
\text { Efficiency }\end{array}$ \\
\hline \multirow{3}{*}{ JIT with IOT } & Pearson Correlation & 1 & $.842^{* * *}$ & $.767^{* * *}$ & $.864^{* *}$ \\
\hline & Sig. (2-tailed) & & .000 & .000 & .000 \\
\hline & $\mathrm{N}$ & 60 & 60 & 60 & 60 \\
\hline \multirow{3}{*}{$\begin{array}{l}\text { TPM whit } \\
\text { IOT }\end{array}$} & Pearson Correlation & $.842^{* * *}$ & 1 & $.634^{* *}$ & $.771^{* * *}$ \\
\hline & Sig. (2-tailed) & .000 & & .000 & .000 \\
\hline & $\mathrm{N}$ & 60 & 60 & 60 & 60 \\
\hline \multirow{3}{*}{$\begin{array}{l}\text { Kaizen with } \\
\text { IOT }\end{array}$} & Pearson Correlation & $.767^{\text {*** }}$ & $.634^{* *}$ & 1 & $.802^{* *}$ \\
\hline & Sig. (2-tailed) & .000 & .000 & & .000 \\
\hline & $\mathrm{N}$ & 60 & 60 & 60 & 60 \\
\hline \multirow{3}{*}{$\begin{array}{l}\text { Project } \\
\text { Efficiency }\end{array}$} & Pearson Correlation & $.864^{* *}$ & $.779^{* *}$ & $.802^{* *}$ & 1 \\
\hline & Sig. (2-tailed) & .000 & .000 & .000 & \\
\hline & $\mathrm{N}$ & 60 & 60 & 60 & 60 \\
\hline
\end{tabular}

**. Correlation is significant at the 0.01 level (2-tailed).

\section{Multiple Regressions}

In multiple regression test, few independent variables (Usage of JIT with IOT,TPM with IOT and Kaizen with IOT material utalization) and one dependent variable (Project Effeciency) tested to protect linear relationship among them.

Table 3: Model Summary of Regression

\begin{tabular}{|c|c|c|c|c|}
\hline \multicolumn{5}{|c|}{ Model Summary } \\
\hline Model & R & R Square & $\begin{array}{c}\text { Adjusted R } \\
\text { Square }\end{array}$ & $\begin{array}{c}\text { Std. Error of the } \\
\text { Estimate }\end{array}$ \\
\hline 1 & $.914^{\mathrm{a}}$ & .835 & .826 & .24019 \\
\hline
\end{tabular}

a. Predictors: (Constant), Kaizen with IOT, TPMwith IOT, JIT with IOT

The table shows that R-Square is .826 , it express that there is strong positive significant relation between independent variables (Usage of JIT with IOT,TPM with IOT and Kaizen with IOT) and dependent variable(Project Effeciency)

\section{ANOVA}

Table 4: ANOVA

\begin{tabular}{|c|l|c|c|c|c|c|}
\hline \multicolumn{7}{|c|}{ ANOVA $^{\text {a }}$} \\
\hline \multirow{3}{*}{1} & Model & Sum of Squares & df & Mean Square & F & Sig. \\
\hline \multirow{3}{*}{1} & Regression & 16.369 & 3 & 5.456 & 94.577 & $.000^{\mathrm{b}}$ \\
\cline { 2 - 7 } & Residual & 3.231 & 56 & .058 & & \\
\cline { 2 - 7 } & Total & 19.600 & 59 & & & \\
\hline
\end{tabular}

a. Dependent Variable: Project Efficiency 


\section{b. Predictors: (Constant), Kaizen with IOT, TPM with IOT, JIT with IOT}

The ANOVA table stated, there are independent variables that have significant linear relationship with Project Effeciency. To express the exact variables, the next table will be explained.

\section{Coefficients}

According to the table above, all $\mathrm{P}$ values are not more than .05. This expressed that all independent variables have significant positive linear relationship Project Effeciency. The B value is the portion of the variable within the overall relationship. According to the above table, JIT with OIT has most noteworthy portion that is .710. So it is the strong independent variable. In the other hand TPM with OIT is the weakest independent variable with the portion of 0.109 .

Table 5: Cofficient Table from Questionnaire SPSS Analysis

\begin{tabular}{|c|c|c|c|c|c|c|}
\hline \multicolumn{7}{|c|}{ Coefficients $^{\mathrm{a}}$} \\
\hline & \multirow{2}{*}{ Model } & \multicolumn{2}{|c|}{ Unstandardized Coefficients } & $\begin{array}{c}\text { Standardized } \\
\text { Coefficients }\end{array}$ & \multirow[t]{2}{*}{$\mathbf{t}$} & \multirow{2}{*}{ Sig. } \\
\hline & & B & Std. Error & Beta & & \\
\hline \multirow{4}{*}{1} & (Constant) & .057 & .159 & & .360 & .720 \\
\hline & JIT with IOT & .710 & .127 & .197 & -4.615 & .000 \\
\hline & TPM with IOT & .109 & .107 & .380 & 3.776 & .000 \\
\hline & $\begin{array}{l}\text { Kaizen with } \\
\text { IOT }\end{array}$ & .405 & .098 & .614 & 7.256 & .000 \\
\hline
\end{tabular}

a. Dependent Variable: Project Efficiency

\section{CONCLUSIONS}

For optimum utilization of construction resources which are material, equipment and labor the following steps have considered.

\section{Planning of Resource Utilization}

For optimal utilization of resources the sufficient planning is required to gain the objectives and scope of work. For this purpose the planning methodology extracted from the methods which have been used in manufacture industries that are JIT method for material utilization, TPM method for equipment utilization and Kaizen method for labor utilization. The result indicated, these mentioned methods have closed correlation for resource utilization. So the construction industries can utilize these methods to get more efficiency in construction projects.

\section{Monitoring and Controlling of Resources}

For better monitoring and controlling of resources, Internet of Things or IOT has been recommended, because the IOT technology is a best choice for close management of construction site. The result of SPSS analysis shows which collected from 60 Male and Female experts of construction management field, that the IOT is one of the productive and efficient concept for close monitoring and controlling of resources.

\section{Integration of Lean Methods \& IOT}

Integration of lean methods with IOT is a concept for construction industries that they can get more profit and can save time and cost on the basis of planning with lean methods and monitoring and controlling with IOT. Because the result in case study and in P-E analysis or Productivity-Efficiency Analysis shows, the difference between conventional method and this recommended method is significant both in productivity and in efficiency in construction project. 


\section{ACKNOWLEDGEMENT}

I would like to take this opportunity to thank Associate Prof. Sandeep Salhotra, Department of Civil Engineering, and Chandigarh University for providing this opportunity to carry out this project. The constant guidance and encouragement received from Associate Prof. Sandeep Salhotra, Head of Department of Civil Engineering has been of great help in carrying out the project work and acknowledged with reverential thanks. We express gratitude to other faculty members of the Civil Department, Chandigarh University for their intellectual support throughout the course the work has gone through the content of the synopsis submitted and found it in order and fit to carry on the proposed studies.

\section{REFERENCES}

1. PMI, The Standard for Project Management, Vol. 53, No. 9. 2017.

2. L. Koskela, "Application of the new production philosophy to construction," Vol. 72, 1992.

3. J. RamaJogi and S. S. Asadi, “Optimal resources utilization in construction industry,” Int. J. Civ. Eng. Technol., vol. 8, no. 1, pp. 273-280, 2017.

4. J. A. Fapohunda, D. Ph, and P. P. Stephenson, "Optimal Construction Resources Utilization : Reflections of Site Managers '," Pacific J. Sci. Technol., Vol. 11, No. 2, pp. 353-365, 2010.

5. B. A. Kumar, “Productivity Increase by Optimum Utilization of Resources,” Vol. 3, No. 7, pp. 576-586, 2017.

6. J. Zhao, O. Seppänen, A. Peltokorpi, B. Badihi, and H. Olivieri, "Real-time resource tracking for analyzing value-adding time in construction,” Autom. Constr., Vol. 104, No. June 2018, pp. 52-65, 2019, doi: 10.1016/j.autcon.2019.04.003.

7. T. Vidhate, "General overview of Lean Management in Construction Industry," Int. Res. J. Eng. Technol., Vol. 5, No. 7, pp. 1999-2004, 2018, doi: ISSN: 2395-0056.

8. S. Kaiafa and A. P. Chassiakos, “A Genetic Algorithm for Optimal Resource-driven Project Scheduling," Procedia Eng., Vol. 123, pp. 260-267, 2015, doi: 10.1016/j.proeng.2015.10.087.

9. S. Tang, D. R. Shelden, C. M. Eastman, P. Pishdad-Bozorgi, and X. Gao, "A review of building information modeling (BIM) and the internet of things (IoT) devices integration: Present status and future trends," Autom. Constr., Vol. 101, No. June 2018, pp. 127-139, 2019, doi: 10.1016/j.autcon.2019.01.020.

10. R. Woodhead, P. Stephenson, and D. Morrey, "Digital construction: From point solutions to IoT ecosystem," Autom. Constr., Vol. 93, No. March, pp. 35-46, 2018, doi: 10.1016/j.autcon.2018.05.004.

11. R. Kanan, O. Elhassan, and R. Bensalem, “An IoT-based autonomous system for workers' safety in construction sites with real-time alarming, monitoring, and positioning strategies,” Autom. Constr., Vol. 88, No. December 2017, pp. 73-86, 2018, doi: 10.1016/j.autcon.2017.12.033.

12. Bakhoum, Es, Gl Garas, and M E Allam. "Sustainability Perspective of Saw-Gang Granite Waste in Concrete Mixes." International Journal of Civil Engineering (IJCE) 4.5 (2015):1-10

13. Prabhu, P. Ganesh, and D. Ambika. "Study on behaviour of workers in construction industry to improve production efficiency." International Journal of Civil, Structural, Environmental and Infrastructure Engineering Research and Development (IJCSEIERD) 3.1 (2013): 59-66.

14. Sarmah, P. U. R. B. A. S. H. R. E. E., et al. "Design, of a Combination of Compost Plant and Landfill for Municipal Solid Waste Management of Guahati City." International Journal of Civil, Structural, Environmental and Infrastructure Engineering Research and Development (IJCSEIERD) 5.4 (2015): 45-52. 
15. Patil, Swati S., and P. P. Bhangale. "Overhead Cost in Construction Industry." International Journal of Industrial Engineering \& Technology (IJIET) 4.2 (2014): 1-6.

16. Udhayakumar, R., and P. Karthikeyan. "Integrating Project Management Tools for Augmenting the Profession of Civil Engineers in M/S URC Construction (P) Ltd., India." International Journal of Civil, Structural, Environmental and Infrastructure Engineering Research and Development (IJCSEIERD) 4.5 (2014): 1-8.

\section{BIOGRAPHIES OF AUTHORS}

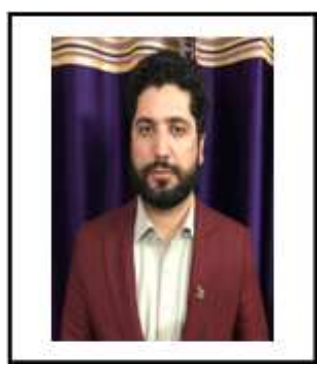

Rafiullah Amiri, M-Tech Research Scholar in Civil Engineering, from Chandigarh University, Punjab, India, completed B-Tech (Civil Engineering) in 2012 from Afghanistan. Having 7 years of experience with local and international NGOs, the private sector.

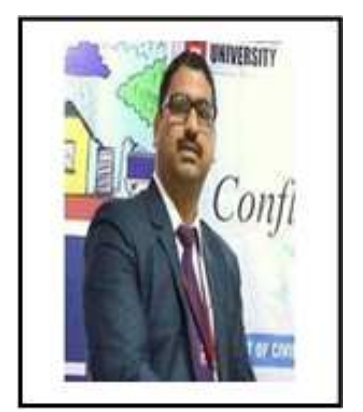

Prof. Sandeep Salhotra having experience of more than 15 years, out of which 10 years of experience are in renowned industries such as Unitech limited and panacea biotech limited. Published more than 15 papers in Scopus indexed journals. Pursuing doctorate from PEC Chandigarh. Member of IAENG 

